\title{
KEPEMIMPINAN TRANSFORMASIONAL, KEPUASAN KERJA DAN KOMITMEN ORGANISASI SEBAGAI MOTIVATOR KINERJA PEGAWAI NEGERI SIPIL
}

\author{
Gerry Suryosukmono* \\ Manajemen, Fakultas Ekonomi dan Bisnis, Universitas Bengkulu, Indonesia
}

\begin{abstract}
Abstrak
Ada berbagai macam faktor yang mempengaruhi kinerja SDM dalam perusahaan diantaranya faktor kepemimpinan mengontrol kinerja bawahannya dan budaya organisasi sebagai dasar menerapkan kinerja baik di dalam pekerjaan ataupun di dalam perilaku. Sebagai tambahan, faktor perilaku inovasi dalam mencari ide baru merupakan faktor yang sangat penting dalam meningkatkan kinerja karyawan. Penelitian ini bertujuan untuk menguji dan menganalisa pengaruh dari kepemimpinan transformasional, budaya organisasi dan perilaku inovasi untuk meningkatkan kinerja karyawan. Total sampel yang diambil berjumlah 80 orang yang ditentukan dengan metode convenient sampling. Metode penelitian diawali dengan melakukan tes validitas dan reliabilitas dengan menggunakan Confirmatory Factor Analysis. Selanjutnya, peneliti menggunakan analisa regresi berganda untuk menguji analisa hipotesis. Hasil penelitian menunjukkan adanya efek yang signifikan antara kepemimpinan transformasional dan budaya organisasi terhadap kinerja karyawan. Selain itu, pengaruh lain juga muncul dari perilaku inovasi meskipun tidak sesignifikan dua variabel sebelumnya. Implikasi teoritis dan implikasi manajerial dijelaskan lebih lanjut di dalam pembahasan penelitian.
\end{abstract}

Kata Kunci: Kepemimpinan Transformasional; Kepuasan Kerja; Komitmen Organisasi; Kinerja Karyawan

\begin{abstract}
Greater autonomy give a more responsibility for region to fulfill people's needs. At consequences, productivity and performance of public employee become a main factor that must be solved. This study aimed to analyze the effect of transformational leadership, job satisfaction and organizational commitment to increase the degree of job performance from public service employees in Bengkulu City. Sample of research include 60 civil servants in the Local Government Unit (SKPD) Bengkulu from Regional Employment Agency (BKD), Regional Development Planning Agency (Bappeda), Narcotics Board (BNN Kota Bengkulu) and Kesbanglinmas using multiple regression analysis. Sample determined by convenience sampling method. This research concludes that transformational leadership, job satisfaction and organizational commitment have significant effect on employee performance in public sector of Bengkulu City. Implications for research and managerial practices were derived from these findings.

Keyword: Transformational Leadership; Job Satisfaction; Organizational Commitment; Employee Performance
\end{abstract}

Article History: Received: (19-02-2020); Revised: (02-04-2020); and Published: (30-04-2020) Copyright (c) 2020 Suryosukmono

How to cite this article: Suryosukmono, G (2020). Kepemimpinan Transformasional, Kepuasan Kerja dan Komitmen Organisasi Sebagai Motivator Kinerja Pegawai Negeri Sipil. Managament Insight: Jurnal Ilmiah Manajemen. 15(1), 1-18. 


\section{PENDAHULUAN}

Undang-Undang Nomor 22 Tahun 1999 yang lalu disempurnakan dengan amandemen yang melahirkan Undang-Undang Nomor 32 Tahun 2004 tentang Pemerintah Daerah memberikan perspektif baru dalam pelaksanaan otonomi daerah. $\mathrm{Hal}$ ini terjadi karena undang-undang tersebut memberikan kewenangan yang penuh dan lebih luas bagi pemerintah daerah untuk mengatur daerahnya sehingga membuka peluang akan terbukanya persaingan antar daerah. Salah satu aspek penting bagi kebijakan otonomi daerah dalam rangka meningkatkan daya saing daerah dengan daerah lainnya di Indonesia, adalah dengan peningkatan pelayanan umum untuk memenuhi kebutuhan masyarakat di daerah tersebut. Kebijakan tersebut tentunya berimplikasi kepada pemerintah daerah yang dituntut untuk memiliki kinerja baik secara organisasi maupun secara sumber daya dalam diri aparatur negara di dalamnya. Selain itu, dengan adanya rencana pemberlakuan remunerasi yang didasarkan pada produktivitas pegawai negeri sipil, tentunya kinerja kerja menjadi salah satu hal yang menjadi prioritas utama.

Penilaian kinerja di lingkungan pegawai negeri sipil (PNS) sendiri dikenal dengan sebutan penilaian pelaksanaan pekerjaan (Peraturan Pemerintah Nomor 10 Tahun 1979). Penilaian kinerja tersebut dilaksanakan menggunakan daftar penilaian pelaksanaan pekerjaan (DP3), dengan unsur-unsur yang terdapat di dalamnya, meliputi : kesetiaan, prestasi kerja, tanggung jawab, ketaatan, kejujuran, kerjasama, prakarsa dan kepemimpinan (hanya dinilai bagi Pegawai Negeri Sipil yang berpangkat Pengatur Muda golongan ruang II/a keatas yang memangku suatu jabatan). Selain itu dalam upaya meningkatkan kinerja sektor publik dan kualitas pelayanan kepada masyarakat, dalam Keputusan Menteri Pemberdayaan Aparatur Negara no 25/KEP/M.PAN/04/2002, diuraikan beberapa keadaan yang terjadi saat ini, seperti kurangnya puasnya masyarakat akan pelayanan yang diberikan aparatur negara, kurangnya integritas, peran pemimpin yang tidak bisa menjadi teladan dan cenderung meminta untuk senantiasa dipatuhi oleh bawahannya, dan kurangnya disiplin dan sanksi yang tegas atas kesalahan yang diperbuat.

Kota Bengkulu yang memiliki domisi wilayah di Provinsi Bengkulu sebagai salah satu daerah yang perlu mendapatkan perhatian dari segi kinerja aparatur negaranya. Hal ini tercemin dari aspek kompetitif yang begitu lemah (Tan \& Merdikawati, 2015) dimana provinsi Bengkulu menempati peringkat 23 dari 33 provinsi pada tahun 2015. Adapun kota Bengkulu sendiri, didasarkan pada penilaian Kementrian PAN pada tahun 2013 dari segi penilaian kinerja mendapatkan kategori C (agak kurang/ memiliki sistem untuk manajemen kinerja tapi kurang dapat diandalkan, perlu banyak perbaikan dan termasuk perbaikan yang mendasar). Meskipun dari segi kinerja, kota Bengkulu mengalami peningkatan dibandingkan tahun sebelumnya yang mendapatkan kategori D (kurang), akan tetapi banyak perubahan yang mesti harus tetap dilakukan. 
Dari berbagai masalah yang dikemukakan di atas, terlihat pentingnya fungsi pemimpin di dalam lingkungan pegawai negeri sipil untuk menjadi contoh dan mampu membuat bawahannya bekerja sesuai dengan tugas dan kewajibannya. Sejalan dengan hal tersebut, peran dan fungsi pemimpin transformasional yang memberikan motivasi dan mampu menjadi figur terbukti memiliki pengaruh positif bagi peningkatan kinerja pegawai di lembaga pemerintahan (Paarlberg \& Perry, 2007) Selain itu, aspek kepuasan kerja dan komitmen organisasi juga menjadi indikator penting di dalam meningkatkan kinerja pelayanan pegawai lembaga publik yang diberikan kepada masyarakat ((Kim, 2005; Turkyilmaz, Akman, Ozkan, \& Pastuszak, 2011; Young, Worchel, \& Woehr, 1998)

Secara keseluruhan penelitian ini mempunyai tujuan untuk meneliti seberapa besar pengaruh kepemimpinan transformasional, kepuasan kerja dan komitmen organisasi dalam meningkatkan kinerja kerja para pegawai negeri sipil di Kota Bengkulu

\section{TINJAUAN PUSTAKA}

Lebih dari 20 tahun terakhir, kinerja menjadi salah satu topik yang sangat menarik di banyak penelitian. Menurut (Campbell, McCloy, Oppler, \& Sager, 1993) kinerja didefinisikan sebagai hal-hal apa saja diinginkan organisasi dalam merekrut karyawan dan karyawan itu dapat melakukannya dengan baik dengan catatan hal itu bisa diukur untuk menyatakan apakah perilaku itu termasuk kinerja atau tidak. Kinerja sendiri harus diukur berdasarkan evaluasi dari proses yang terjadi untuk menghasilkan suatu barang (Motowidlo, Borman, \& Schmit, 1997). Dalam pendapat lainnya kinerja diasumsikan menjadi sebuah kriteria yang objektif untuk menilai karyawan yang memiliki potensi yang tinggi dalam melakukan pekerjaannya (Cappelli, 2008).

Mengenai aspek kepemimpinan transformasional adalah (Burns, 1978) yang pertama kali mengenalkan konsep pemimpin transformasional dan kepemimpinan transaksional dalam konteks kepemimpinan politik. Seperti yang dikutip (Meindl, Conger, \& Kanungo, 2001), kepemimpinan transformasional dan kepemimpinan transaksional dibedakan dari sikap yang ditawarkan oleh pemimpin kepada bawahannya.

Kepemimpinan transformasional mengajukan tujuan yang berfokus pada kebutuhan intrinsik yang lebih tinggi, bukan hanya bersifat jangka pendek. Sedangkan kepemimpinan transaksional berfokus pada sumber daya yang akan ditawarkan kepada bawahannya dan bersifat sesaat. Dengan kata lain kepemimpinan transformasional terjadi ketika pemimpin berusaha memperhatikan dan meningkatkan kepentingan pengikutnya. Selain itu pemimpin yang transformatif mampu menginspirasi bawahannya untuk mengutamakan kepentingan dan kebaikan kelompok di atas kepentingan pribadinya masing-masing. (Givens, 2008) (Longshore \& Bass, 1987) berdasarkan teori kepemimpinan transformasional dari konsep (Burns, 1978) melakukan beberapa modifikasi dengan merumuskan teori yang berpendapat 
kepemimpinan transformasional dan kepemimpinan transaksional adalah konsep yang berbeda serta menyusun perilaku yang menggambarkan perilaku kepemimpinan transformasional dan kepemimpinan transaksional. (Longshore \& Bass, 1987) mengistilahkan kepemimpinan transformasional sebagai "Fours I's", yang meliputi "pengaruh individual (individualized influence), motivasi inspiratif (inspirational motivation), stimulasi intelektual (intellectual stimulation), dan pertimbangan individual (individualized consideration)".

Ketika berbicara mengenai kepuasan kerja, ada banyak konsep dan teori yang membahas definisi kepuasan kerja dari para ahli. Pendapat paling umum dikemukakan oleh (Locke, 1976) yang menyatakan kepuasan kerja sebagai suatu hal yang menyenangkan atau emosi positif yang muncul karena penilaian yang memuaskan atas pekerjaan atau pengalaman kerja dari seseorang. Dalam pengertian yang hampir sama, (Judge, Cranny, Smith, \& Stone, 1994) mendefinisikan kepuasan kerja sebagai reaksi emosional yang bersifat afektif terhadap pekerjaan yang dimilikinya. Hal ini terjadi karena gap yang sangat kecil antara hasil kerja yang dicapai dan ekspektasi yang diharapkan. Dalam pendapat lain dikatakan kepuasan kerja adalah bagaimana perasaan karyawan mengenai pekerjaan dan aspek - aspek yang berbeda dari pekerjaan tersebut. (Rowden \& Conine, 2005).

(Kalleberg, 1977) melihat kepuasan kerja adalah orientasi afektif dari fungsi dan peran dari pekerjaan yang dipunyai seseorang secara keseluruhan. Hal ini berarti menurut (Kalleberg, 1977) kepuasan kerja tidak bisa hanya diukur dari salah satu aspek dalam pekerjaan saja tetapi harus dalam kerangka secara keseluruhan pekerjaan itu sendiri. Sehingga kepuasan kerja dipandang sebagai konsep yang terdiri atas satu kesatuan memandang pekerjaan secara utuh.

Komitmen organisasi menjadi faktor lain yang tidak kalah penting dari dua faktor sebelumnya untuk meningkatkan kinerja karyawan. (Mowday, Steers, \& Porter, 1979) menyatakan komitmen organisasi dapat berjalan karena adanya persamaan nilai dari individu dan organisasi. Akan tetapi, (Allen \& Meyer, 1993) membantah pendapat tersebut dan menyempurnakannya dengan pendapat komitmen organisasi bukan hanya tumbuh karena persamaan nilai saja akan tetapi komitmen organisasi sebagai ekspresi psikologis (keinginan, kebutuhan, kewajiban) yang menjelaskan hubungan antara karyawan dan organisasi dimana karyawan merasa menjadi anggota organisasi dan terkait keputusan untuk melanjutkan atau keluar dari organisasi.

Dalam perkembangannya, komitmen organisasi sebagai suatu proses psikologis memiliki tahapan-tahapan yang dimulai dari proses instrumen atau keterlibatan yang digunakan untuk terlibat dengan harapan mendapatkan extrinsic reward, identifikasi atau disebut sebagai keterlibatan dalam aktivitas organisasi disebabkan karena keinginan yang tumbuh dalam diri individu dan internalisasi atau keterlibatan karena kesesuaian antara nilai-nilai yang dianut individu dengan nilai-nilai yang berlaku di dalam perusahaan. (C. O’Reilly \& Chatman, 1986). Selain itu para ahli juga 
mendefinisikan komitmen organisasi dalam berbagai pengertian seperti ekspresi positif dan loyalitas (C. A. O’Reilly \& Caldwell, 1980) motivasi dan keterlibatan (Scholl, 1981) , dan perilaku seperti kinerja dan kepatuhan yang sangat tinggi terhadap aturan organisasi (Angle \& Perry, 1981). (Curtis \& Wright, 2001) mengemukakan komitmen telah didefinisikan sebagai kekuatan identifikasi individu yang berada dalam sebuah organisasi. (Curtis \& Wright, 2001) menjelaskan bahwa konsep ini dapat dipecah menjadi tiga komponen, yaitu kemauan untuk tetap menjadi anggota di organisasi dalam organisasi, keyakinan dan penerimaan terhadap nilai dan tujuan organisasi, dan kesediaan bekerja keras dan berkontribusi sebagai bagian dari organisasi.

Menurut (Weick, 1984), karyawan yang memiliki komitmen organisasi yang tinggi adalah karyawan yang lebih stabil dan lebih produktif sehingga pada akhirnya juga lebih menguntungkan bagi organisasi. (Singh, 2008) juga menguatkan pendapat itu dengan asumsi komitmen organisasi merupakan tingkat kepercayaan dan peneriman pekerja terhadap tujuan organisasi dan mempunyai keinginan untuk tetap ada dalam organisasi tersebut sehingga indikator penilaiannya dapat tergambar dalam statistik kehadiran dan masuk keluarnya pekerja dari organisasi (turnover).

Komitmen organisasi memiliki tiga dimensi komitmen, yang terdiri dari komitmen afektif, komitmen normatif dan komitmen berkelanjutan memiliki fungsi yang sangat strategis karena karyawan yang memiliki komitmen organisasi yang tinggi maka akan turut memacu kinerja yang maksimal. (Kam, Morin, Meyer, \& Topolnytsky, 2016) (Yousef, 2000) menyatakan bahwa hubungan antara komitmen organisasi dan hasil kerja dari kepuasan kerja dan kinerja adalah positif dan signifikan. Komitmen organisasi juga mempengaruhi outcomes (keberhasilan) suatu organisasi. Dalam penelitian empiris lainnya, terlihat komitmen organisasi yang bersifat afektif berpengaruh positif dalam mendukung kinerja pegawai lembaga pemerintahan dan kinerja organisasi secara keseluruhan (Liou \& Nyhan, 1994; Romzek, 1989)

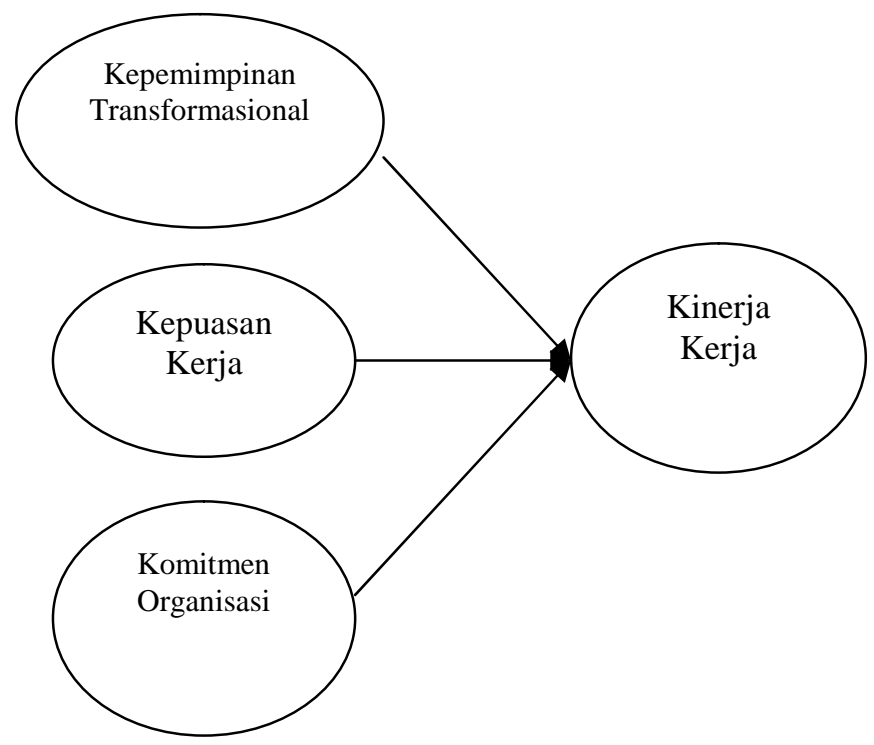

Gambar 1. Kerangka Konseptual 
Sebanyak lebih dari 35 penelitian melaporkan adanya pengaruh positif antara kepemimpinan transfomasional dan kinerja bawahannya (Kirkpatrick \& Locke, 1996) Bukti penelitian menunjukkan ketika pemimpin membangun perilaku yang visioner yang merupakan ciri-ciri pemimpin yang transformasional akan membuat bawahannya merasa pekerjaan mereka akan berarti dan akan meningkatkan kinerja mereka dalam pekerjaan (Bass \& Riggio, 2005; Piccolo \& Colquitt, 2006; Purvanova, Bono, \& Dzieweczynski, 2006; Trottier, Van Wart, \& Wang, 2008). Senada dengan hal tersebut, kepemimpinan transformasional akan berkorelasi positif dengan motivasi pengikut dan kinerja kerja mereka (Judge \& Piccol, 2004).

Dari uraian teori dan pandangan peneliti di atas, maka hipotesa penelitian yang diajukan penulis adalah:

\section{H1 : Kepemimpinan Transformasional berpengaruh positif terhadap kinerja kerja} pegawai negeri sipil.

Berbagai studi penelitian yang dilakukan telah banyak menunjukkan hubungan yang positif antara kepuasan kerja dan kinerja karyawan. Hasil penelitian sebelumnya di Amerika Serikat yang dilakukan pada staf restoran (Babin \& Boles, 1996), industri perhotelan (Hochwarter, Perrewé, Ferris, \& Brymer, 1999) bank dan unit kredit(Allred, 2001), perawat rumah sakit (Newman \& Maylor, 2002) menunjukkan adanya pengaruh yang positif dan signifikan antara kepuasan kerja terhadap kinerja karyawan (Huang \& Lai, 2014).

Kepuasan kerja secara statistik sangat signifikan untuk menjadi determinan dari produktivitas karyawan di dalam sektor manufaktur (Böckerman \& Ilmakunnas, 2012). Selain itu, kepuasan kerja secara intrinsik turut andil mempengaruhi kinerja karyawan dari segi kinerja seacara tugas dan kontekstual (Hosie, Willemyns, \& Sevastos, 2012) . Sependapat dengan hal tersebut, (Edwards, Bell, Arthur, \& Decuir, 2008) juga menyimpulkan adanya hubungan yang berkorelasi positif antara kepuasan kerja secara keseluruhan dan kinerja pekerjaan seorang karyawan. Dalam penelitiannya, mereka tidak menemukan adanya perbedaan antara hubungan kepuasan kerja dengan kinerja baik dari segi tugas ataupun dari segi kontekstual pekerjaanya.

Penelitian mengenai efek kepuasan kerja terhadap kinerja juga dilakukan oleh (Huang \& Lai, 2014) terhadap industri pariwisata di Taiwan, khususnya pada karyawan hotel. Hasil penelitian menunjukkan bahwa kepuasan kerja karyawan memiliki pengaruh yang positif dan signifikan terhadap kinerja karyawan dan hasil ini mendukung studi - studi sebelumnya. Dalam penelitian lainnya, (Fu \& Deshpande, 2014) dan (Yousef, 1998) juga menemukan korelasi positif antara kepuasan kerja dengan dan kinerja karyawan di perusahaan asuransi di Cina dan lembaga pemerintahan di Uni Emirat Arab. Senada dengan hal itu, (Abdullah \& Wan, 2013) mengatakan bahwa selain faktor insentif maka faktor kepuasan kerja adalah faktor utama yang menunjang kinerja karyawan. 
Hipotesa penelitian yang didapatkan dari rumusan teori di atas adalah sebagai berikut:

\section{H2 : Kepuasan kerja berpengaruh positif terhadap kinerja kerja pegawai negeri sipil.}

(T. A. Wright \& Bonett, 2002) menjelaskan bahwa komitmen organisasi dan kinerja karyawan sangat berkaitan erat dimana masa jabatan menjadi variabel yang menghubungkan antara keduanya. Hal ini juga dipengaruhi tipe pekerjaan utamanya antara manajemen dan pekerja teknis dimana kinerja pekerja teknis cenderung lebih mudah diukur saat pekerja teknis memiliki komitmen organisasi dibandingkan pihak manajemen. Kinerja pekerjaaan sangat erat kaitannya dengan komitmen berkelanjutan, terlebih lagi jika dikombinasikan dengan komitmen afektif (Meyer, Stanley, \& Parfyonova, 2012).

Penelitian sebelumnya yang dilakukan oleh (Leroy, Palanski, \& Simons, 2012) melalui model penelitiannya, juga mengasumsikan bahwa komitmen organisasi secara afektif berhubungan sangat signifikan dengan kinerja dan peran kerja dari karyawan. Mereka menyimpulkan bahwa karyawan yang memiliki komitmen organisasi cenderung mengembangkan upaya yang lebih besar pada pekerjaan yang berdampak pada kinerja mereka. Hubungan yang kuat antara komitmen organisasi dan kinerja kerja para karyawan juga didukung penelitian yang dilakukan (de Cuyper \& de Witte, 2011) dan (Li, Ahlstrom, \& Ashkanasy, 2010) dengan kesimpulan bahwa komitmen organisasi harus senantiasa ditumbuhkan lewat fungsi dan desain organisasi untuk meningkatkan kinerja karyawan dalam menyelesaikan pekerjaannya

Dari uraian teori dan pandangan peneliti di atas, maka hipotesa penelitian yang diajukan penulis adalah:

\section{H3 :Komitmen Organisasi berpengaruh positif terhadap kinerja kerja pegawai negeri sipil.}

\section{METODE PENELITIAN}

Penelitian ini bertujuan untuk menguji pengaruh antara kepemimpinan transformasional, kepuasan kerja dan komitmen organisasi terhadap kinerja kerja pegawai negeri sipil di kota Bengkulu. Metode penelitian yang digunakan adalah analisis regresi berganda dengan objek penelitian adalah pegawai negeri sipil di kota Bengkulu. Sampel penelitian ini adalah 60 pegawai negeri sipil di Satuan Kerja Pemerintah Daerah (SKPD) kota Bengkulu yang berasal dari empat departemen yaitu Badan Kepegawaian Daerah, Badan Perencanaan Pembangunan Daerah, Badan Narkotika kota Bengkulu dan Badan Kesbanglinmas. Teknik pengambilan sampel dengan metode convenience sampling, yaitu suatu metode pemilihan sampel yang dipilih dari elemen populasi yang datanya mudah diperoleh peneliti (Indriantoro \& Supomo, 2016) 
Penelitian ini menggunakan kuisioner untuk mengukur aspek kepemimpinan transformasional dengan mengadopsi dan memodifikasi pernyataan kuesioner dari penelitian yang dilakukan oleh (Wahab, Fuad, Ismail, \& Majid, 2014) didasarkan pada dimensi penelitian dari (Avolio, Bass, \& Jung, 1999). Kuesioner dipilih karena sering digunakan dalam berbagai penelitian termasuk penelitian yang dilakukan di Malaysia sehingga teruji validitas dan reliabilitasnya.

Pengukuran mengenai kepuasan kerja menggunakan Job Satisfaction Questionnaire (JSQ) yang berasal dari penelitian Cellucci \& De Vries (1978) dan telah banyak digunakan di dalam penelitian karena telah teruji reliabilitas dan validitasnya (Deshpande, 1996; Vitell \& Davis, 1990). Penelitian ini mengadaptasi dan memodifikasi kuisioner dari JSQ Cellucci \& DeVries (1978) yang telah dikembangkan oleh (Fu, 2014) dengan cara menterjemahkan pernyataan yang ada di kuisioner dalam bahasa Indonesia disertai penyesuaian makna.

Kuisioner mengenai komitmen organisasi yang digunakan dalam penelitian ini adalah modifikasi dan adopsi dari Organizational Commitment Questionnaire (OCQ) yang dikembangkan oleh (Allen \& Meyer, 1993). Pengukuran ini sudah diakui kevalidan dan reliabilitasnya melalui penelitian yang dilakukan (Chen \& Francesco, 2003) Dalam perkembangannya, kuisioner ini kembali digunakan oleh (Fu \& Deshpande, 2014) dalam penelitian.

Kuisioner mengenai kinerja kerja karyawan ini diadaptasi dari penelitian (Bish \& Kabanoff, 2014) yang menggabungkan penelitian yang dilakukan (Williams \& Anderson, 1991) dari segi kinerja tugas dan penelitian yang dilakukan (Van Scotter \& Motowidlo, 1996) dari segi kontekstual dan digunakan dalam penelitian ini setelah disesuaikan makna dan terjemahannya dalam bahasa Indonesia. 


\section{HASIL PENELITIAN}

Tabel 1. Karakteristik Responden

\begin{tabular}{cccc}
\hline Variable & Kategori & Frekuensi & $\%$ \\
\hline Jenis Kelamin & Laki-laki & 36 & 60 \\
Usia & Perempuan & 24 & 40 \\
& $20-30$ tahun & 18 & 30 \\
& $30-40$ tahun & 21 & 35 \\
Tingkat pendidikan & $40-50$ tahun & 17 & 28.33 \\
& Di atas 50 tahun & 4 & 6.67 \\
Domisi tempat tinggal & SMA & 11 & 18.33 \\
& S1 & 33 & 55 \\
Tingkat Pendapatan & Pascasarjana (S2 dan S3) & 16 & 26.67 \\
& Di Kota Bengkulu & 48 & 80 \\
& Di luar kota Bengkulu & 12 & 20 \\
& Di bawah Rp 2,000,000 & 5 & 8.33 \\
& Rp. 2,000,001 - Rp 3,000,000 & 13 & 21.67 \\
& Rp. 3,000,001 - Rp 4,000,000 & 22 & 36.67 \\
\hline
\end{tabular}

Sumber: Data Primer (2019)

Tabel 1 menunjukkan rangkuman identitas dari responden dimana mayoritas responden adalah laki-laki (60\%) dengan usia dominan adalah 30-40 tahun (35\%) disusul usia 20-30 tahun (30\%). Selain itu tingkat pendidikan responden kebanyakan berasal dari lulusan S1 (55\%), domisi daerah berada di Kota Bengkulu (80\%), dan tingkat penghasilan mayoritas berkisar antara Rp. 3,000,001 - Rp 4,000,000 (36.67\%), dan di atas $\operatorname{Rp~4,000,000~(33.33\% ).~}$

Tabel 2 Statistik Deskriptif

\begin{tabular}{l|r|r|r}
\hline & Mean & $\begin{array}{c}\text { Std. } \\
\text { Deviation }\end{array}$ & N \\
\hline Kinerja kerja (Y1) & 26.6000 & 8.42957 & 60 \\
Kepemimpinan & 19.8500 & 3.95236 & 60 \\
Transformasional (X1) & & & \\
Kepuasan Kerja (X2) & 14.7000 & 2.16521 & 60 \\
Komitmen Organisasi & 24.9333 & 4.32128 & 60 \\
(X3) & & & \\
\hline
\end{tabular}

Sumber: Data Primer (2019)

Tabel 2 menunjukkan statistik deskriptif yang berisi deskripsi rata-rata dan standar deviasi dari keempat variabel, baik variabel independen maupun variabel dependen. Dari tabel tersebut terlihat nilai skor rata-rata dan standar deviasi tertinggi berdasarkan pengukuran responden adalah variabel X3 (komitmen organisasi),diikuti 
oleh variabel X1 (kepemimpinan transformasional), dan variabel X2 (kepuasan kerja). Adapun jumlah $\mathrm{N}$ adalah banyaknya kasus yang diolah dari responden di penelitian

Tabel 3. Validitas dan Reliabilitas

\begin{tabular}{|c|c|c|c|c|}
\hline \multirow[t]{2}{*}{ Variabel Latent } & \multirow{2}{*}{$\begin{array}{l}\text { Variabel } \\
\text { Manifes }\end{array}$} & Estimasi & \multirow{2}{*}{$\begin{array}{l}\text { Construct } \\
\text { Reliability }\end{array}$} & \multirow{2}{*}{$\begin{array}{l}\text { Variance } \\
\text { Extract }\end{array}$} \\
\hline & & Factor Loading & & \\
\hline \multirow{5}{*}{$\begin{array}{l}\text { Kepemimpinan } \\
\text { Transformasional }\end{array}$} & 1 & 0.68 & \multirow{5}{*}{0,878} & \multirow{5}{*}{0,548} \\
\hline & 2 & 0.65 & & \\
\hline & 7 & 0.63 & & \\
\hline & 8 & 0.75 & & \\
\hline & 9 & 0.61 & & \\
\hline \multirow[t]{4}{*}{ Kepuasan Kerja } & 6 & 0.74 & \multirow{4}{*}{0,786} & \multirow{4}{*}{0,539} \\
\hline & 7 & 0.85 & & \\
\hline & 8 & 0.83 & & \\
\hline & 9 & 0.87 & & \\
\hline \multirow{7}{*}{$\begin{array}{l}\text { Komitmen } \\
\text { Organisasi }\end{array}$} & 1 & 0,74 & \multirow{7}{*}{0,911} & \multirow{7}{*}{0,525} \\
\hline & 2 & 0,56 & & \\
\hline & 4 & 0,63 & & \\
\hline & 5 & 0,58 & & \\
\hline & 6 & 0.76 & & \\
\hline & 7 & 0.68 & & \\
\hline & 9 & 0.59 & & \\
\hline \multirow[t]{5}{*}{ Kinerja Karyawan } & 1 & 0,86 & \multirow{5}{*}{0,827} & \multirow{5}{*}{0,591} \\
\hline & 2 & 0,79 & & \\
\hline & 3 & 0,66 & & \\
\hline & 4 & 0,78 & & \\
\hline & 5 & 0.65 & & \\
\hline
\end{tabular}

Sumber: Data diolah (2019)

Note: *Valid jika VE $>0.5$

**Reliabel jika Construct Reliability $>0.6$

Berdasarkan tabel di atas menunjukkan bahwa seluruh dimensi dan indikator dari konstruk memiliki nilai faktor muatan standar (standardized loading factor) di atas 0,5. Adapun Construct Reliability (CR) dari seluruh dimensi dan konstruk di atas 0,6 dan Variance Extract (VE) seluruhnya di atas 0,5. Dengan demikian dapat disimpulkan bahwa seluruh variabel penelitian, dimensi dan indikator pada semua variabel memiliki reliabilitas dan validitas yang baik. 
Tabel 4. Uji Hipotesis

\begin{tabular}{l|r|r|r}
\hline Model & $\begin{array}{r}\text { Standardized } \\
\text { Coefficients }\end{array}$ & \multicolumn{1}{|c|}{ Sig. } \\
\cline { 2 - 3 } & \multicolumn{1}{|c|}{ Beta } & & \\
\hline (Constant) & 1.074 & 12.620 & .000 \\
Kepemimpinan & & & .000 \\
Transformasional & & & .000 \\
Kepuasan Kerja & -.431 & 74.935 & .016 \\
Komitmen Organisasi & & -2.486 & \\
\hline
\end{tabular}

Sumber: Data Primer (2019)

Tabel 4 menunjukkan hasil regresi nilai koefisien kepemimpinan transformasional, kepuasan kerja, dan komitmen organisasi yang menjadi bukti yang mendukung signifikansi hubungan yang terjadi antar variabel. Nilai koefisien regresi dengan nilai $p$ $<0.05$ menunjukkan bahwa kepemimpinan transformasional (0.000), kepuasan kerja (0.000), dan komitmen organisasi (0.016) secara signifikan berpengaruh kepada peningkatan kinerja kerja.

\section{PEMBAHASAN}

Hasil penelitian menunjukkan adanya kesesuaian dengan hipotesis 1 yang menunjukkan bahwa kepemimpinan transformasional secara signifikan berpengaruh kepada kinerja kerja. Hal ini sesuai dengan penelitian (B. E. Wright, Moynihan, \& Pandey, 2012) yang memberikan pernyataan bahwa di dalam konteks pegawai negeri, kepemimpinan tranformasional bermanfaat dalam meningkatkan kinerja pelayanan kepada masyarakat dengan berorientasi pada visi dan misi yang disusun menjadi motivasi untuk lebih atraktif, saling mendukung sesama rekan kerja dan memiliki produktivitas baik di dalam lembaga pemerintahan (Brewer \& Selden, 2000). (Luthans, 2012) juga menyatakan bahwa kepemimpinan transformasional membawa keadaan menuju kinerja tinggi pada organisasi yang menghadapi tuntutan pembaharuan dan perubahan.

Dalam konteks pegawai negeri sipil di kota Bengkulu, adanya keinginan untuk meningkatkan kinerja organisasi membuat para atasan mulai berusaha mengakomodir peran dan fungsi bawahannya. Adanya tuntutan pembaruan yang dicanangkan pemerintah kota Bengkulu, meskipun dengan banyak tantangan yang timbul terbukti tidak menyurutkan semangat para pemimpin untuk bersama-sama mengajak para bawahannya untuk menggenjot prestasi kerja Kota Bengkulu. Kebiasaan-kebiasaan positif yang mulai dilakukan oleh Kepala Departemen dan Dinas terkait seperti penyelenggaraan briefing sebelum bekerja, evaluasi, adanya proses konseling, mentoring dan pemberian motivasi keagamaan terhadap pegawai negeri menjadi salah satu upaya nyata yang terbukti positif untuk meningkatkan kinerja kerja karyawan. 
Untuk menguji hipotesis 2 di dalam hasil penelitian terbukti kepuasan kerja terbukti memberi pengaruh positif kepada kinerja kerja pegawai. Hasil ini didukung (Yousef, 1998) yang menemukan korelasi positif antara kepuasan kerja dengan dan kinerja pegawai lembaga pemerintahan di Uni Emirat Arab. Pegawai negeri sipil di kota Bengkulu menunjukkan kepuasan kerja yang memiliki efek positif kepada kinerja mereka. Hal ini tercermin dari hubungan yang baik antar rekan kerja dan atasan, promosi jabatan yang bekesinambungan, faktor upah yang dirasa memadai dan faktor beban pekerjaan yang cukup.

(LeRouge, Nelson, \& Blanton, 2006) dan (Hakim, 2012) menggarisbawahi faktor kepuasan kerja adalah faktor utama yang membuat kinerja karyawan dalam hal ini pegawai negeri sipil menjadi meningkat dan berefek secara keseluruhan. Karyawan yang tidak memiliki kepuasan kerja akan melakukan banyak tindakan seperti tidak mematuhi peraturan, bekerja malas-malasan dan lain sebagainya yang tentunya akan merugikan kinerja mereka dan organisasi. Hal itu dapat dilihat bahwa seseorang dengan tingkat kepuasan tinggi akan menunjukan sikap yang positif terhadap kinerjanya, sedang seseorang yang tidak puas dengan pekerjaannya maka akan menunjukan sikap yang negatif terhadap pekerjaan itu.

Dalam menguji hipotesis 3, juga terlihat bahwa komitmen organisasi memiliki pengaruh yang signifikan dengan kinerja kerja pegawai. Pegawai yang mempunyai keterlibatan tinggi dalam bekerja dan tidak mempunyai keinginan keluar dari organisasi, maka hal ini merupakan modal dasar untuk mendorong produktifitas yang tinggi. (Harrison \& Hubbard, 1998). Penelitian sebelumnya yang dilakukan oleh (McNeese-Smith, 1996) dan (Benkhoff, 1997) juga mengasumsikan bahwa individu yang memiliki komitmen organisasi cenderung mengembangkan upaya yang lebih besar pada pekerjaan yang berdampak pada kinerja mereka.

(Dessler, 1999) menyimpulkan di dalam penelitiannya, pegawai yang memiliki komitmen tinggi akan memiliki tingkat kehadiran yang tinggi dan memiliki masa kerja di organisasi yang lebih tinggi dibandingkan orang yang berkomitmen rendah. Mereka akan bekerja lebih keras dan memiliki kinerja yang lebih tinggi dibandingkan pegawai yang memiliki komitmen rendah. Dari hasil penelitian terlihat komitmen organisasi pegawai negeri sipil di kota Bengkulu berimplikasi positif pada kinerja mereka. Adanya rasa keinginan untuk berpartisipasi di dalam pembangunan daerah juga didorong oleh faktor pekerjaan sebagai PNS yang memiliki kompensasi yang cukup dan rasa "aman" dalam pekerjaan membuat komitmen organisasi yang lebih bersifat continuance (berkelanjutan) dan normatif berkontribusi positif dalam kinerja mereka

\section{KESIMPULAN DAN SARAN}

Dari beberapa hasil penelitian yang didapatkan dapat ditarik beberapa kesimpulan. Pertama, adanya hubungan pengaruh yang sangat signifikan antara kepemimpinan transformasional dan kinerja kerja pegawai. Disini akan terlihat pentingnya peran pemimpin sebagai fasilitator yang baik dan juga sebagai mentor yang dapat membantu para anggota organisasi atau karyawan tadi untuk dapat menyesuaikan diri dengan iklim kerjanya. Kepala departemen atau dinas terkait adalah ujung tombak yang diharapkan dapat menerjemahkan tujuan organisasi ke dalam 
tindakan nyata dan mengontrol tindakan karyawan untuk senantiasa berada pada kinerja yang baik dalam rangka mencapai tujuan organisasi.

Ketika pemimpin menunjukkan kepemimpinan yang baik, para karyawan akan berkesempatan untuk mempelajari perilaku yang tepat untuk berhadapan dengan pekerjaan mereka. Demikian pula halnya dengan birokrasi publik, pemimpin memegang peranan yang sangat strategis. Berhasil atau tidaknya birokrasi publik menjalankan tugas-tugasnya sangat ditentukan oleh kualitas pimpinannya, karena kedudukan pemimpin sangat mendominasi semua aktivitas yang dilakukan. Dalam organisasi publik, bawahan bekerja selalu tergantung pada pimpinan. Bila pimpinan tidak memiliki kemampuan memimpin, maka tugas-tugas yang sangat kompleks tidak dapat dikerjakan dengan baik dan berimplikasi pada produktivitas kerja yang semakin meningkat.

Kedua, adanya hubungan yang positif dan signifikan terjadi antara kepuasan kerja dan kinerja karyawan. Faktor kepuasan kerja yang didapatkan karyawan sangat penting untuk dijaga oleh organisasi dalam rangka meningkatkan kinerja dan penyelesaian hasil yang berhasil dicapai. Dalam konteks organisasi publik, kepuasan kerja pegawai negeri memiliki peran penting terutama dalam pembentukan citra lembaga pemerintahan di dalam opini masyarakat. Citra negatif seperti malas-malasan, produktivitas kerja yang rendah, absensi kehadiran yang tidak tepat waktu menjadi citra yang sebelumnya melekat dalam diri pegawai negeri sipil. Tentu dengan adanya kepuasan kerja PNS yang berusaha diakomodir oleh pemerintah daerah dalam hal ini seperti pemberian beban kerja dan tantangan kerja yang memacu kinerja, aspek upah yang berbasis produktivitas, adanya hubungan yang hangat antara rekan kerja dan atasan serta jenjang promosi yang adil menjadi berbagai macam cara yang dapat dilakukan untuk meningkatkan kepuasan kerja bagi karyawan.

Ketiga, hasil penelitian yang menunjukkan komitmen organisasi sebagai salah satu faktor yang secara positif mempengaruhi kinerja PNS di Kota Bengkulu. Pemerintah daerah Kota Bengkulu dapat melihat bahwa komitmen organisasi melibatkan antara kesesuaian individu karyawan baik berupa motivasi, efek positif, kompensasi ataupun nilai-nilai yang dianut dengan berbagai hal yang berada di organisasi. Hal ini akan mengakibatkan karyawan tersebut merasa penting untuk menjadi bagian dari organisasi itu, berkontribusi dan membesarkan organisasi melalui kegiatan yang dilakukannya. Pada akhirnya, karyawan itu akan merasa betah dan melihat organisasi sebagai tempat menyalurkan potensi dirinya sehingga tidak melihat pilihan selain bertahan di organisasi.

Penelitian ini memiliki beberapa batasan yang dapat dikembangkan pada penelitian ke depannya. Perlunya perbandingan objek penelitian dengan sampel dari daerah lain tentunya akan membuka kemungkinan-kemungkinan baru dari hasil yang didapat. Selain itu penelitian hanya berfokus pada metode sebab-akibat, yang menilai perilaku pegawai dalam waktu dan kondisi tertentu, sehingga ke depannya disarankan menggunakan metode longitudinal untuk menilai dan mengetahui perkembangan perilaku pegawai dari waktu ke waktu. Hal ini akan memberikan gambaran yang lebih luas dalam menilai kinerja PNS di kota Bengkulu. Terakhir, jumlah sampel penelitian yang terlalu sedikit mungkin belum bisa memberikan generalisasi kondisi kinerja PNS kota Bengkulu. Oleh karena itu ke depannya, diharapkan jumlah sebaran dan kuantitas 
sampel yang lebih banyak saat melakukan penelitian berikutnya tentang kinerja PNS di Kota Bengkulu.

\section{DAFTAR PUSTAKA}

Abdullah, A. A., \& Wan, H. L. (2013). Relationships of Non-Monetary Incentives, Job satisfaction and Employee Job Performance. International Review of Management and Business Research. https://doi.org/10.1111/issr.12066

Allen, N. J., \& Meyer, J. P. (1993). Organizational commitment: Evidence of career stage effects? Journal of Business Research. https://doi.org/10.1016/01482963(93)90042-N

Allred, A. T. (2001). Employee evaluations of service quality at banks and credit unions. International Journal of Bank Marketing. https://doi.org/10.1108/02652320110695468

Angle, H. L., \& Perry, J. L. (1981). An Empirical Assessment of Organizational Commitment and Organizational Effectiveness. Administrative Science Quarterly. https://doi.org/10.2307/2392596

Avolio, B. J., Bass, B. M., \& Jung, D. I. (1999). Re-examining the components of transformational and transactional leadership using the multifactor leadership questionnaire. Journal of Occupational and Organizational Psychology. https://doi.org/10.1348/096317999166789

Babin, B. J., \& Boles, J. S. (1996). The effects of perceived co-worker involvement and supervisor support on service provider role stress, performance and job satisfaction. Journal of Retailing. https://doi.org/10.1016/S0022-4359(96)90005-6

Bass, B. M., \& Riggio, R. E. (2005). Transformational leadership: Second edition. In Transformational Leadership: Second Edition. https://doi.org/10.4324/9781410617095

Benkhoff, B. (1997). Ignoring commitment is costly: New approaches establish the missing link between commitment and performance. Human Relations. https://doi.org/10.1177/001872679705000604

Bish, A. J., \& Kabanoff, B. (2014). Star performers: Task and contextual performance are components, but are they enough? Asia Pacific Journal of Human Resources. https://doi.org/10.1111/1744-7941.12017

Böckerman, P., \& Ilmakunnas, P. (2012). The job satisfaction-productivity nexus: A study using matched survey and register data. Industrial and Labor Relations Review. https://doi.org/10.1177/001979391206500203

Brewer, G. A., \& Selden, S. C. (2000). Why Elephants Gallop: Assessing and Predicting Organizational Performance in Federal Agencies. Journal of Public Administration Research and Theory. https://doi.org/10.1093/oxfordjournals.jpart.a024287

Burns, J. M. (1978). Leadership, 1978. In Many translations and later editions. https://doi.org/10.1007/978-4-431-09429-6_20

Campbell, J. P., McCloy, R. A., Oppler, S. H., \& Sager, C. E. (1993). A theory of performance. Personnel Selection In Organizations.

Cappelli, P. (2008). Talent management for the twenty-first century. Harvard Business Review. 
Chen, Z. X., \& Francesco, A. M. (2003). The relationship between the three components of commitment and employee performance in China. Journal of Vocational Behavior. https://doi.org/10.1016/S0001-8791(02)00064-7

Curtis, S., \& Wright, D. (2001). Retaining employees - the fast track to commitment. Management Research News. https://doi.org/10.1108/01409170110782964

de Cuyper, N., \& de Witte, H. (2011). The management paradox: Self-rated employability and organizational commitment and performance. Personnel Review. https://doi.org/10.1108/00483481111106057

Deshpande, S. P. (1996). The impact of ethical climate types on facets of job satisfaction: An empirical investigation. Journal of Business Ethics. https://doi.org/10.1007/BF00411800

Dessler, G. (1999). How to earn your employees commitment. Academy of Management Executive. https://doi.org/10.5465/ame.1999.1899549

Edwards, B. D., Bell, S. T., Arthur, W., \& Decuir, A. D. (2008). Relationships between facets of job satisfaction and task and contextual performance. Applied Psychology. https://doi.org/10.1111/j.1464-0597.2008.00328.x

$\mathrm{Fu}, \mathrm{W}$. (2014). The Impact of Emotional Intelligence, Organizational Commitment, and Job Satisfaction on Ethical Behavior of Chinese Employees. Journal of Business Ethics. https://doi.org/10.1007/s10551-013-1763-6

Fu, W., \& Deshpande, S. P. (2014). The Impact of Caring Climate, Job Satisfaction, and Organizational Commitment on Job Performance of Employees in a China's Insurance Company. Journal of Business Ethics. https://doi.org/10.1007/s10551013-1876-y

Givens, R. (2008). Transformational leadership: The impact on organizational and personal outcomes. Emerging Leadership Journeys.

Hakim, L. (2012). Membangun Budaya Organisasi Unggul sebagai Upaya Meningkatkan Kinerja karyawab di Era Kompetitif. Jurnal Manajemen Dan Bisnis. https://doi.org/https://doi.org/10.23917/benefit.v15i2.1342

Harrison, J. K., \& Hubbard, R. (1998). Antecedents to organizational commitment among mexican employees of a U.S. firm in Mexico. Journal of Social Psychology. https://doi.org/10.1080/00224549809600416

Hochwarter, W. A., Perrewé, P. L., Ferris, G. R., \& Brymer, R. A. (1999). Job Satisfaction and Performance: The Moderating Effects of Value Attainment and Affective Disposition. Journal of Vocational Behavior. https://doi.org/10.1006/jvbe.1998.1659

Hosie, P., Willemyns, M., \& Sevastos, P. (2012). The impact of happiness on managers' contextual and task performance. Asia Pacific Journal of Human Resources. https://doi.org/10.1111/j.1744-7941.2012.00029.x

Huang, S.-M., \& Lai, W.-H. (2014). A Study of the effect of incentive system on job performance -Locus of control as a moderator. The Journal of International Management Studies.

Indriantoro, N., \& Supomo, B. (2016). Metodologi Penelitian Bisnis Untuk Akuntansi \& Manajemen. In Yogyakarta : Penerbit BPFE.

Judge, T. A., Cranny, C. J., Smith, P. C., \& Stone, E. F. (1994). Job Satisfaction: How People Feel about Their Jobs and How It Affects Their Performance. 
Administrative Science Quarterly. https://doi.org/10.2307/2393502

Judge, T. A., \& Piccol, R. F. (2004). Transformational and transactional leadership: A meta-analytic test of their relative validity. Journal of Applied Psychology. https://doi.org/10.1037/0021-9010.89.5.755

Kalleberg, A. L. (1977). Work Values and Job Rewards: A Theory of Job Satisfaction. American Sociological Review. https://doi.org/10.2307/2117735

Kam, C., Morin, A. J. S., Meyer, J. P., \& Topolnytsky, L. (2016). Are Commitment Profiles Stable and Predictable? A Latent Transition Analysis. Journal of Management. https://doi.org/10.1177/0149206313503010

Kim, S. (2005). Individual-level factors and organizational performance in government organizations. Journal of Public Administration Research and Theory. https://doi.org/10.1093/jopart/mui013

Kirkpatrick, S. A., \& Locke, E. A. (1996). Direct and indirect effects of three core charismatic leadership components on performance and attitudes. Journal of Applied Psychology. https://doi.org/10.1037/0021-9010.81.1.36

LeRouge, C., Nelson, A., \& Blanton, J. E. (2006). The impact of role stress fit and selfesteem on the job attitudes of IT professionals. Information and Management. https://doi.org/10.1016/j.im.2006.08.011

Leroy, H., Palanski, M. E., \& Simons, T. (2012). Authentic Leadership and Behavioral Integrity as Drivers of Follower Commitment and Performance. Journal of Business Ethics. https://doi.org/10.1007/s10551-011-1036-1

Li, Y., Ahlstrom, D., \& Ashkanasy, N. M. (2010). A multilevel model of affect and organizational commitment. Asia Pacific Journal of Management. https://doi.org/10.1007/s10490-010-9193-9

Liou, K.-T., \& Nyhan, R. (1994). Dimensions of Organizational Commitment in the Public Sector: An Empirical Assessment. Public Administration Quarterly.

Locke, E. A. (1976). The nature and causes of job satisfaction. In Handbook of Industrial and Organizational Psychology.

Longshore, J. M., \& Bass, B. M. (1987). Leadership and Performance beyond Expectations. The Academy of Management Review. https://doi.org/10.2307/258081

Luthans, F. (2012). Organizational Behaviour An Evidence-Based Approach. In McGrawHill/Irwin.

McNeese-Smith, D. (1996). Increasing employee productivity, job satisfaction, and organizational commitment. Hospital and Health Services Administration.

Meindl, J. R., Conger, J. A., \& Kanungo, R. N. (2001). Charismatic Leadership in Organizations. Administrative Science Quarterly. https://doi.org/10.2307/2667134

Meyer, J. P., Stanley, L. J., \& Parfyonova, N. M. (2012). Employee commitment in context: The nature and implication of commitment profiles. Journal of Vocational Behavior. https://doi.org/10.1016/j.jvb.2011.07.002

Motowidlo, S. J., Borman, W. C., \& Schmit, M. J. (1997). A theory of individual differences in task and contextual performance. Human Performance. https://doi.org/10.1207/s15327043hup1002_1

Mowday, R. T., Steers, R. M., \& Porter, L. W. (1979). The measurement of organizational commitment. Journal of Vocational Behavior. 
https://doi.org/10.1016/0001-8791(79)90072-1

Newman, K., \& Maylor, U. (2002). Empirical evidence for "the nurse satisfaction, quality of care and patient satisfaction chain." International Journal of Health Care Quality Assurance. https://doi.org/10.1108/09526860210421482

O'Reilly, C. A., \& Caldwell, D. F. (1980). Job choice: The impact of intrinsic and extrinsic factors on subsequent satisfaction and commitment. Journal of Applied Psychology. https://doi.org/10.1037/0021-9010.65.5.559

O'Reilly, C., \& Chatman, J. (1986). Organizational Commitment and Psychological Attachment. The Effects of Compliance, Identification, and Internalization on Prosocial Behavior. Journal of Applied Psychology. https://doi.org/10.1037/00219010.71.3.492

Paarlberg, L. E., \& Perry, J. L. (2007). Values management: Aligning employee values and organization goals. American Review of Public Administration. https://doi.org/10.1177/0275074006297238

Piccolo, R. F., \& Colquitt, J. A. (2006). Transformational leadership and job behaviors: The mediating role of core job characteristics. Academy of Management Journal. https://doi.org/10.5465/AMJ.2006.20786079

Purvanova, R. K., Bono, J. E., \& Dzieweczynski, J. (2006). Transformational leadership, job characteristics, and organizational citizenship performance. Human Performance. https://doi.org/10.1207/s15327043hup1901_1

Romzek, B. S. (1989). PERSONAL CONSEQUENCES OF EMPLOYEE COMMITMENT. Academy of Management Journal. https://doi.org/10.2307/256438

Rowden, R. W., \& Conine, C. T. (2005). The impact of workplace learning on job satisfaction in small US commercial banks. Journal of Workplace Learning. https://doi.org/10.1108/13665620510597176

Scholl, R. W. (1981). Differentiating Organizational Commitment From Expectancy as a Motivating Force. Academy of Management Review. https://doi.org/10.5465/amr.1981.4285698

Singh, P. (2008). Job analysis for a changing workplace. Human Resource Management Review. https://doi.org/10.1016/j.hrmr.2008.03.004

Tan, K. G., \& Merdikawati, N. (2015). Assessing regional competitiveness in Indonesia. International Journal of Business and Systems Research. https://doi.org/10.1504/IJBSR.2015.071842

Trottier, T., Van Wart, M., \& Wang, X. (2008). Examining the nature and significance of leadership in government organizations. Public Administration Review. https://doi.org/10.1111/j.1540-6210.2007.00865.x

Turkyilmaz, A., Akman, G., Ozkan, C., \& Pastuszak, Z. (2011). Empirical study of public sector employee loyalty and satisfaction. Industrial Management and Data Systems. https://doi.org/10.1108/02635571111137250

Van Scotter, J. R., \& Motowidlo, S. J. (1996). Interpersonal facilitation and job dedication as separate facets of contextual performance. Journal of Applied Psychology. https://doi.org/10.1037/0021-9010.81.5.525

Vitell, S. J., \& Davis, D. L. (1990). The relationship between ethics and job satisfaction: An empirical investigation. Journal of Business Ethics. https://doi.org/10.1007/BF00382842 
Wahab, J. A., Fuad, C. F. M., Ismail, H., \& Majid, S. (2014). Headmasters' transformational leadership and their relationship with teachers' job satisfaction and teachers' commitments. International Education Studies. https://doi.org/10.5539/ies.v7n13p40

Weick, K. E. (1984). Behavior in Organizations: Understanding and Managing the Human Side of Work. PsycCRITIQUES. https://doi.org/10.1037/023221

Williams, L. J., \& Anderson, S. E. (1991). Job Satisfaction and Organizational Commitment as Predictors of Organizational Citizenship and In-Role Behaviors. Journal of Management. https://doi.org/10.1177/014920639101700305

Wright, B. E., Moynihan, D. P., \& Pandey, S. K. (2012). Pulling the Levers: Transformational Leadership, Public Service Motivation, and Mission Valence. Public Administration Review. https://doi.org/10.1111/j.1540-6210.2011.02496.x

Wright, T. A., \& Bonett, D. G. (2002). The moderating effects of employee tenure on the relation between organizational commitment and job performance: A metaanalysis. Journal of Applied Psychology. https://doi.org/10.1037/00219010.87.6.1183

Young, B. S., Worchel, S., \& Woehr, D. J. (1998). Organizational commitment among public service employees. Public Personnel Management. https://doi.org/10.1177/009102609802700304

Yousef, D. A. (1998). Satisfaction with job security as a predictor of organizational commitment and job performance in a multicultural environment. International Journal of Manpower. https://doi.org/10.1108/01437729810216694

Yousef, D. A. (2000). Organizational commitment: A mediator of the relationships of leadership behavior with job satisfaction and performance in a non-western country. Journal of Managerial Psychology. https://doi.org/10.1108/02683940010305270 